[Sellers, M. (2004). Peaceful Perspectives: Peace Education, Educating for Peace. New Zealand Annual Review of Education, 13, 225-248]

\section{Peaceful Perspectives: Peace Education, Educating for Peace}

\section{MARG SELLERS}

\section{Abstract:}

Peace education was engendered by the Cold War, and with the thawing of East-West relations the educational interest in peace also dissipated. However, recent events have revoked the calm and initiated a global war against terrorism. In this paper I revisit the role of peace in education to rediscover and re-present how peaceful perspectives are inherent in learning and teaching. I outline a peaceful interpretation of the curriculum and suggest that a mandate for this perspective should be a priority.

\section{S}

eptember 11, 2001, will remain etched in many minds, if for no other reason than the sudden realisation that we are all potentially vulnerable to war - a new kind of war that requires merely a creative (mis)use of modern technology. Having a Peace Education lecture to attend that day was synchronistic, yet it appeared ironic that peace studies or peace education is not a part of the formal curriculum in Aotearoa New Zealand (AoNZ) ${ }^{1}$ schools. Every week the media cautions us that it is naive to assume we are safe in our homes and communities. The need to address issues of direct violence becomes ever more important for more people. However, on September 12 (AoNZ time), the Professor of Peace Studies at Bradford University emphasised the complementary need to address indirect violence. He said we need to go beyond an analysis of the direct violence of terrorism, and to investigate the indirect, structural, institutional violence that inheres within Westernism and which manifests as direct violence within, between, and among nations, societies, communities, families, and individuals. ${ }^{2}$ While addressing indirect violence is not the responsibility of education alone, but also the responsibility of all

\section{Marg Sellers}

social, political, and economic institutions, it is an important aspect of peace education. As Wulf (1992) says, educating for peace

... focuses not only on war or direct violence between nations and in the international system but also on intrasocial conditions engendering violence, including elements of violence in family upbringing and formal schooling. (p. 5)

Considering how violence pervades our society at all levels, it appears short-sighted to be focusing on increasing law and order, and unwise not to be including peace education in the curriculum. However, my proposition is that the absence of explicit reference to peace education within the New Zealand Curriculum Framework (NZCF) (Ministry of Education [MOE], 1993a) does not preclude children from being educated about the meaning of peace.

In this article I present a case for peace education being effected through current curriculum, within classrooms and schools which embrace a non-violent ethos. This then leads to peaceful learning experiences for students and potentially contributes to a more peaceful and less violent society. Firstly, I explain the need for compatibility between the what and how of peace education, and review literature which considers the concept. Next, the New Zealand Curriculum Framework and curriculum statements will be analysed, with a focus on possibilities for peace education within them. Finally, I suggest possible options for future research and policy development within the area of peace education.

\section{There is No Way to Peace: Peace is the Way}

If "the medium is the message", ${ }^{3}$ then the interconnectedness between means and end, and form and content within peace education cannot be understated. The need for such congruence within peace education is explained by the aphorism commonly attributed to Mahatma Ghandi: "There is no way to peace, peace is the way." In other words, if the message is peace, then the ways of communicating it must be peaceful. This means that peaceful learning environments must resonate with social justice and human dignity and be committed to equity (Reardon, 1997), with curricula being socially relevant and using appropriate methodology (Hicks, 1988). Put differently, "There is little point in teaching about peace if we ignore how we teach it" (Catholic Education Office \& the New South Wales Department of Education 
(CEO \& NSWDOE), 1987, p. 139). Such unity of learning, that is, uniting issues of the formal curriculum (the content) with the informal curriculum (the process-oriented and metacognitive aspects) is particularly relevant to peace education. Bringing together the formal knowledge of making sense of the world with the informal curriculum, namely, skills, attitudes and values associated with learning to understand ourselves and learning to live with others, is important if peace education is to have credibility and integrity. That is, a unity of what is taught with how it is taught is crucial (New South Wales Department of Education, 1988).

\section{Theoretical Understandings of Peace Education}

Different people interpret peace, and ways of achieving it, in different ways. However, common broad definitions appear to be founded in Galtung's conceptualisations of peace (1976, cited in Hicks, 1987). Firstly, the problems of peace, namely, violence and war, inequality, injustice, environmental damage and an ideology of alienation; and secondly, the presence of peace, which requires non-violence, economic welfare, social justice, ecological balance and participatory processes. Problems of peace are broadly categorised as negative peace, meaning the negation - the absence or opposite - of war and direct violence. The presence of peace, or positive peace, is not only the absence of structural violence but also the presence of a wide range of welfare indicators that promote social cohesion.

Adding to Galtung's notions of negative and positive peace, the CEO \& NSWDOE (1987) offer an open-ended synthesis of these two abstractions by expanding on the action orientation or praxis of positive peace. This approach is less concerned with states of being which promote peace, and more concerned with building alternative futures by means of a theory-action synthesis. It includes creative social change toward preventing war; a critical focus on structures which lead to violence; building alternative futures; the notion that peace and justice are inseparable in social change; and that war and social injustice are a continuum. Within this perspective, peace education is conceived of holistically, rather than in a fragmentary way, so that considerations of how subject matter is taught become increasingly important.

Various approaches to understanding peace collectively indicate the complexity surrounding peace education (Hicks, 1988; Reardon,
1997; Sharp, 1984). Sharp discusses peace in terms of strength, that is, armed deterrence; world order; abolition of power relationships through social justice, democracy, and economic well-being; conflict mediation and resolution; intrapersonal peace; and the use of feminist approaches (pp. 250-261). Hicks (1988) includes fields of personal and social education; development education (that is, addressing economic inequity); and political education (p. 172). Reardon (1997) considers multicultural studies towards domestic tranquillity and international understanding and environmental education from a human rights perspective (pp. 24-34). These interpretations of how peace education might be conceptualised and actualised illustrate the multiplicity of interrelationships likely to be involved. From such complexity we can infer that as well as the medium being the message, the message is the medium.

\section{Peace Education in Practical Terms}

Peace education can be thought of in terms of educating about peace, educating for peace, and educating in peace. Educating about peace is commonly considered in terms of peace studies, which is defined as "the systematic study of the causes of war and the conditions of peace" (Stephenson, 1989, p. 18). It tends towards specific courses and study units that are taught at specific times.

Educating for peace is embraced by the term peace education within the literature. It is less compartmentalised, more inclusive, interdisciplinary, and is about integrating issues of peace into existing subjects. It may include systematic studies of war and peace, and it "involves an active re-examination of existing subject methodologies, questions of school structures, and raises considerations about the consistency between the content and style in teaching" (CEO \& NSWDOE, 1987, p. 138). Thus peace education is interested not only in the formal and informal curriculum, but also in the hidden curriculum, the latter being a structure of indirect violence in that it reflects and covertly reproduces the unequal power relationships underpinning our society (Adams, Clark, Codd, O'Neill, Openshaw \& Waitere-Ang, 2000, pp. 242-246). Confronting ${ }^{4}$ the hidden curriculum, then, becomes an essential aspect of educating for peace.

Educating in peace is also part of peace education in that not only the content and process of teaching is important, but also the context in which it happens. Context involves an atmosphere of co-operation, 
trust and sensitivity where children are respected as people with ideas that are acceptable and legitimate (Burnley, 1983, cited in CEO \& NSWDOE, 1987). So, while we are teaching about peace, and children are learning in peace, we are simultaneously educating for peace.

Bjerstedt (1992) takes a slightly different perspective and distinguishes between peace education as text, which is explicit (that is, direct information and discussions about issues of war), and peace education as context, which is implicit (nurturing values conducive to peaceful behaviour). School ethos, classroom environments, pedagogical practices, and learning processes all contribute to contextual aspects of peace education. This is most broadly expressed in the concept of educating for peace, which embraces both the contextual and the textual. Educating for peace thus expresses a concern for teaching methods, content, and contextual issues and highlights the need for compatibility between all three aspects educating about peace, in peace and for peace. This ensures that the values of co-operation, participation, dialogue, and positive peace are reflected in the organisation, activity, relationships, and attitudes within schools and their classrooms.

However, it is necessary to point out that the terms peace studies and peace education have different meanings in different parts of the world. In the AoNZ literature they have tended to be interchangeable in that both are used in discussions about specific curriculum conten and also participatory, democratically-styled education (Collinge, 1994; Department of Education, 1986). While Buckland, Jones and Duncan (1990) say peace education should be more about "how to think, not what to think" (p. 6), my preference is for a more complex reading of educating for peace. This involves ongoing processes that minimise the risk of doing peace at certain times, and at the same time encouraging being peaceful/peaceable at all times - in other words, living peace. Within this notion of living peace, my intention is for "living" to be understood ambiguously, both as an adjective and a verb, making for a complexity of understanding among doing, being and knowing, emphasising the inseparability of all three. Peace in all its complexity then becomes a dynamic, generative part of schooling and school life, rather than being static, fixed and compartmentalised. Again, this affirms that not only is the medium the message, but also that the message becomes the medium.

\section{Criticisms of Peace Education}

The statement that "the movement for Peace Studies in schools is part of a trend towards the politicisation of education" (Cox \& Scruton, 1984, p. 7) may be perceived as being incontrovertibly biased towards particular political ends, thus undermining democratic purposes that inhere within notions of peace. However, as Freire (1974) says, there is no neutral educational process, it is always political - education is either a strategy for maintaining the status quo or a means of liberation. In everyday terms, this is not to suggest that teachers intend to indoctrinate. Rather, the intention is to develop critical thinkers (Collinge, 1994).

However, it would be naive to assume that all opinions about peace are free from ideological impositions. Yet, if educating for peace aims to engender concern and involvement - embedded in both rationale and feelings - then peace education becomes pointless without an "aspiration of preparing or even leading to political action" (Wulf, 1992, p. 9). Also, given our individual subjectivities, our perceptions and understandings of "reality" can never be value-free, although acknowledgement of this inevitable bias possibly strengthens the integrity of views held. Hare (1981, cited in Collinge, 1994) helps unravel such dilemmas in saying that an effective way of countering such distortion is to "encourage the development of critical values in children" (p. 41). The recognition that indoctrination, whether real or perceived, in any area of the curriculum, is a risk within any (non-neutral) educational system, affirms the relevance of peace education as part of developing the critical consciousness fundamental to living peace.

Promoting the developing of such skills in critically analysing political "information", regardless of orientation, also confronts criticisms that claim peace education encourages attitudes of "weakness and appeasement" (CEO \& NSWDOE, 1987, p. 142). My observation is that the harmonious and mindful awareness which peace education seeks is unlikely to develop such disadvantage. Rather, it is more likely to develop an attitudinal strength, which embraces respect and responsibility. Similarly, the notion that peace education may frighten children by discussing issues of war is dismantled by Hutchinson's (1993) study in which he actively listened to young people's voices on the future. It, in fact, highlighted the need to discuss their fears for the future with children, so as to empower 
them to engage constructively with, and make choices for, the future, rather than simply accept it as a fait accompli.

Simultaneously, Hutchinson (1993) dispels another criticism, namely, that peace education detracts from curricula basics. If children are going to be empowered to make responsible choices about their future, they need to be able to negotiate broader social literacies than a "back-to-basics" curriculum allows. As Collinge (1994) says, if we approach peace education "with a concern for educational skills and attitudes as much as for content, [this] provides an answer for many critics of peace education who accuse it of bias and indoctrination" (p. 42). In fact, we are enabling children to become "independently thinking and questioning adults" (p. 49). Educating for peace is then about learning living peace.

\section{Educating for Peace Within the New Zealand Curriculum Framework}

American professor Robert Muller says, "I think there is not a single subject or discipline in which the teacher could not make a contribution to peace and a better world" (in Bjerstedt, 1992, p. 28). He continues; "This involves a little effort of new thinking and paradigm change" (p. 29, italics added), although Aspin describes it as "considerable effort" (1984, p. 146). Regardless of this difference in expression, both are certain there is no problem more urgent than attaining a just and lasting peace. Within the New Zealand Curriculum Framework, the health and physical education and social studies curricula are commonly considered to be the subject areas into which discussions and investigations about peace are most readily and appropriately incorporated. Although, if Muller is correct, teachers of other subjects can also address issues of peace and conflict, not only as regards content (the "what"), but also in relation to process (the "how"). Despite the absence of a curriculum statement specifically for peace studies or peace education, possibilities for educating for peace are evident within the principles, essential learning areas, essential skills, and attitudes and values of the framework

\section{The principles}

A relatively simple a pproach is to consider educating for peace in terms of the implementation of a peace perspective within the framework Broadly speaking, the following aspects of the principles align with a peace perspective (adapted from NSWDOE, 1988):
- Treaty of Waitangi - acknowledging our bicultural identity, including te reo, nga tikanga Māori;

- Multicultural education - intercultural awareness and understanding of immigrant minorities, particularly Pacific Peoples;

- Non-sexist policy - ongoing reduction of direct and indirect violence based on gender;

- Environmental education - living in harmony rather than in conflict with our planetary ecosystem;

- Personal development - learning peaceful relationships, conflict resolution skills;

- Student welfare - school ethos that is respectful of diverse learning communities, and ensures peaceful classrooms.

While the NZCF recognises the formal curriculum and also learning associated with the informal curriculum (for example, classroom interactive behaviours), there is no recognition of the existence of the hidden curriculum and its negative impacts (Adams et al., 2000, p. 244) on students and learning. Interestingly, Te Whāriki (MOE, 1996) refers to both "direct" and "indirect" educational experiences within the curriculum (p. 10) - the indirect aspect being that which is hidden. As a structure of indirect violence, the hidden curriculum must be confronted in a thoroughgoing approach to educating for peace. But how can we deal with that which is hidden? To understand how this structural violence may be faced up to, dealt with, and/or disrupted, we need to look at the (explicit) formal and (relatively implicit) informal curriculum

\section{The Essential Learning Areas}

The seven essential learning areas of the formal curriculum are designed to provide a "broad and balanced" education (MOE, 1993a p. 8) and equip students to become effective participants in society, economically and socially. This overall goal can be seen as a part of living peace and also as a way of working towards it. In attempting to determine the extent to which the NZCF provides for peace education, I suggest that knowledge objectives of a peace perspective relate to the following concepts: conflict; peace; justice; power; social change and continuity, that is, preserving what is valuable and modifying what is undesirable; gender; ethnicity; role models of peacemaking; ecology; 
interdependence (economic, environmental, and communications); and futures, both probable and preferable alternatives (NSWDOE, 1988, pp. 7-8).

Within each essential learning area of the NZCF there are aspects that relate to the above concepts. Although in the following each area is considered separately, they are interconnected. For example: language learning is integral to all subjects; issues of science and technology arise in social studies and vice versa; the Arts curriculum specifies links with all other areas (MOE, 2000, pp. 95-98), as does technology (MOE, 1995, pp. 20-21); and mathematics links with all other subjects (MOE, 1997, p. 9).

Language and languages

Language learning develops students' confidence and ability in using the spoken and written word, and includes both English and other languages, such as Chinese and French. Peace-related aspects in the NZCF are: listening openly towards understanding how people think and behave (from the personal to the global); critical evaluation of messages received from others, literature, and the media; the crucial nature of language in transmitting values and culture; and use of non-discriminatory language (MOE, 1993a, p. 10).

Buckland et al. observe, "Language reflects and influences the way people think, the way they feel about themselves, and the way they relate to others" (1990, pp. 9-10). Thus, as well as being necessary to learning in all curricular subjects, language is fundamental to developing quality intrapersonal and interpersonal relationships, that is, to creating peace within oneself, and between/among people, communities, and nations. However, we need to remain alert to the fact that language can also be destructive - that it can be used to manipulate and control, and that it can be gender-, race-, and class-biased. Confronting such language is confronting a structure of violence.

Mathematics

Mathematics is essential to effectively participating in work and everyday life. An open reading of the NZCF suggests mathematics has the potential to contribute to developing knowledge about peace and conflict through learning to collect, organise, and interpret data, and establish patterns and relationships; also through developing problem-solving skills (MOE, 1993a, p. 11). Buckland et al. (1990), show no connection between mathematics and peace education on their peace studies continuum of overlapping subject areas, although the actual mathematics continuum does overlap with creative and aesthetic development, practical abilities, and living in society, all of which are part of the peace studies continuum. Howson (1994) is of a similar view in saying there are more promising areas than mathematics for the development of social and co-operative skills perhaps unsurprising, given that he grants primacy to the abstract over the contextual within mathematics teaching and learning. However, Developing Mathematics Programmes (MOE, 1997a) pays considerable attention to socio-economic barriers to learning; providing a supportive learning environment including accommodating different ways of learning; problem-solving and learning co-operatively involving teamwork, developing a sense of belonging, shared responsibility, and promoting positive social interaction (pp. 19-29). All of these are aspects of educating for peace.

Science

Science develops students' experience and understanding of the living, material, physical, and technological constituents of the world, and how people interact with their environment. Also, students learn how people use scientific knowledge and methods, learn about the influence these have on their lives (considering gender, culture, and background), and on the environment. Consonant with a peace perspective, the NZCF provides for addressing ecological balance and harmony among all life forms, including people and environmental factors (MOE, 1993a, p. 12). Also, the science curriculum (MOE, 1993b) aims to "recognise, respect, and respond to the educational needs, experiences, achievements, and perspectives of all students: both female and male; of all races and ethnic groups; and of differing abilities and disabilities" (p. 11).

Considering the environment and ecological responsibility, Mische points out that it is not the "unschooled and illiterate who are perpetuating the gravest environmental harm" (1992, p. 37), but those from consumptive, wasteful societies that science (and technology) has shaped. Schools thus need to prepare students to be confident and responsible in using and controlling science and technology. Environmental education, which to some extent is addressed within the science curriculum, is seen by Wahlström (1992) as a means of changing culturally learned behaviour to enable peace and ecological 
responsibility. At this point the interconnectedness of science, technology, and social studies becomes apparent as part of the what and how of education for peace.

Technology

Technology explores the use of knowledge, skills, and physical resources to solve practical problems, and pervades all aspects of our lives. It is this pervasiveness of technology - the positive and negative affects and effects on people and their environments - that links with a peace perspective. Understanding how technology "both shapes and is shaped by society" (MOE, 1993a, p. 13) is integral to peaceful co-existence. Peace education, per se, or looking at technology from a peaceful perspective of ecological balance and harmony, is a potential mediating factor in technological development and progress to prevent harmful effects on various groups of people and the environment. Wessells (1993) points out that while the myth exists that technology has caused environmental problems, it is as unfounded as the myth that assumes technology will fix them. What is needed is a focus on the idea that it is people who create and apply technology. Also needed is a paradigm shift of values, social practices and how we think about the world, towards emphasising sustainability rather than domination. Of necessity, technology then links with social studies as a vehicle for peace.

Social Sciences ${ }^{6}$

Social studies is closely aligned with educating for peace. Through both content and process, it explicitly and implicitly deals with issues intrinsic to peace, namely: social organisation; culture and heritage; place and environment; time, continuity, and change; and resources and economic activity. It develops students' understanding and experiences about how people organise their societies to meet their physical, social, emotional, and spiritual needs, in relation to societal (family, community, national, international), political, and economic means and ends. This enables them to participate confidently and responsibly in informed ways. Students are challenged to evaluate human behaviour critically, and to consider values and viewpoints which differ. Concern for social justice, the welfare of others, acceptance of cultural diversity, and respect for the environment are values fundamental to social studies, as are attributes such as initiative, effort, and responsibility. Economic processes of societies are also studied (MOE, 1993a, p. 14).
The importance of developing students' "understanding and experience of how people relate and work together in social, political, and economic ways" (Buckland et al., 1990, p. 10) is commonly accepted in society, although what this means in theory and practice varies among individuals, groups, communities, cultures, and nations. This immediately emphasises the importance of conflict resolution (within the health and physical education curriculum) to enable peaceable and peaceful relationships and living.

The Arts

The Arts contribute to a peace perspective in that they are a form of personal and social expression which crosses boundaries of communication and understanding among and within nations, cultures, and among people. They are a means by which students investigate their own and others' values, and of recognising aesthetic and spiritual dimensions of life (MOE, 1993a, p. 15). As Buckland et al. say, the Arts are a means whereby students can "reflect upon and respond to the way human relationships are expressed and ... examine the implications for their own behaviour" (1990, p. 10).

Health and Physical Well-being ${ }^{7}$

Regardless of its implicitly lower hierarchical positioning within the curriculum, health and physical well-being are fundamental to all learning areas. As with social studies, this area of learning is closely aligned with educating for peace. Health "encompasses the physical, social, emotional, intellectual, and spiritual dimensions of a person's growth" (MOE, 1993a, p. 16). It is integral to personal and social well-being and achievement as students develop confidence in themselves, their abilities, and their learning. It enables them to take responsibility for their own physical well-being and acknowledge the contribution they make to the well-being of others. Within this essential learning area there is a focus on developing relationship skills to enable participation in a wide variety of social activities.

In all four strands of the health and physical education curriculum statement (MOE, 1999), possibilities for educating for peace are more obvious than in any other learning area. Examples of possibilities are:

- Personal Health and Physical Development involves personal growth and development; regular physical activity; safety and risk management; and personal identity and self-worth (p. 28). Within this, students will "analyse attitudes and values and take actions 
that contribute to their personal identity and self-worth" (p. 58). This acknowledges that intra-personal development is crucial to harmonious interactions with others and the environment.

- Movement Concepts and Motor Skills involves movement skills; positive attitudes and challenge; science and technology; and social and cultural factors (p. 29). Students will "develop and apply knowledge and understanding of the social and cultural factors that influence people's involvement in physical activity" (p. 58). This is about understanding, accepting and valuing self and others, as well as acknowledging expressions of individual and cultural difference.

- Relationships with Other People involves issues of relationships; identity, sensitivity, and respect; and interpersonal skills (p. 28). One achievement aim is that students will "use interpersonal skills effectively to enhance relationships" (p. 58), and a Level 8 objective states that students will "critically analyse attitudes, values, and behaviours that contribute to conflict and identify and describe ways of creating more harmonious relationships" (p. 60). Of all the documentation, this objective is the most explicit reference to educating for peace.

- Healthy Communities and Environments involves societal attitudes and beliefs; community resources; rights, responsibilities, and laws; people and the environment (p. 29). This strand includes "understand[ing] the interdependence between people and their surroundings and us[ing] this understanding to help create healthy environments" (p. 58). This concerns the interrelationships between people, technology, and physical and social environments towards socio-ecological balance and harmony.

Tikanga Māori, cultural and gender inclusiveness, and requirements of students with special abilities and needs are also addressed. Regardless of there being no explicit reference to peace education, peace inheres within this part of the curriculum, and opportunities abound for educating for peace.

\section{The Essential Learning Skills}

Concepts for a peace perspective are included within the curriculum framework, as indicated by implicit and/or explicit reference about how students may study and learn about: Causes of conceptual states of being; ${ }^{8}$ different perspectives within them; methods by which they are enacted; agencies (people, communities, nations) that work toward achieving them; and past, present, and future indicators of their existence. These criteria then guide the following analysis of the essential learning skills.

The skill groups are defined as communication, numeracy, information, problem-solving, self-management and competitive, social and co-operative, physical, and work and study skills (MOE, 1993a p. 17). Communication skills (e.g., listening, speaking, reading, and writing) relate directly to English as well as indirectly to all other subjects, and are fundamental to learning. Similarly, social and co-operative skills (e.g., developing good relationships with others) are part of the social studies curriculum, but also are important to learning in all other areas. Numeracy and physical skills relate directly to the formal mathematics and physical education curricula respectively, although some processes involved (for example, mathematical logic and reasoning) have applications in all subject areas, as does the physical skill of relaxation. Information skills relate to all learning areas. The remaining skills, namely, problem-solving, self-management and competitive, and work and study skills are integral to the informal curriculum in that they are skills which enable students to "achieve their potential and to participate fully in society" (MOE, 1993a, p. 17).

Obviously, it is the social and co-operative skills that align most fully with a peace perspective. These skills include issues of relationships; responsibility; participation appropriate to various social and cultural settings; respect for rights and difference; consideration of others; and negotiating skills (MOE, 1993a, pp. 19-20). But other skills are also relevant. Problem-solving skills develop critical and reflective thinking, this being crucial to analysing problems from a variety of different perspectives. Work and study skills enable students to work "effectively, both independently and in groups" (p. 20).

However, there is an inherent problem within the self-management and competitive skills area. Developing selfmanagement skills is a part of personal well-being, involving "constructive approaches to challenge and change, stress and conflict, competition, and success and failure" (p. 19). But, what are these "constructive" approaches intended to achieve? Are they to enhance personal development and support social, co-operative skills, or are they to promote the notion of competition? The section heading, "self-management and competitive skills", implies personal 
development towards individualistic ends. Thus, what arguably purports to impart a peace perspective that emphasises co-operation has an underlying competitive agenda - putting self-management to the fore masks the competitive intentions. Given the current market-orientation of education, since the introduction of Tomorrow's Schools, there is the sense that even the development of social and co-operative skills is designed to serve the economy rather than provide for social means and ends. The question then arises, as to whether this economic agenda is the basis of, or is the hidden curriculum per se. Evaluating the attitudes and values as set down in the NZCF may offer some clues, as these "along with knowledge and skills, are integral" to the framework (p. 21).

\section{Attitudes and values}

While the NZCF (MOE, 1993a) presents attitudes and values as being pivotal $^{9}$ to the curriculum, it devotes a scant page to the topic (p. 21). Attitudes are defined as "the feelings or dispositions towards things, ideas, or people which incline a person to certain types of action"; values are defined as "internalised sets of beliefs or principles of behaviour" that are expressed in the ways that individuals and groups think and act. Further, attitudes (of students, teachers, parents, communities) towards learning "strongly influence the process, quality, and outcomes of both learning and assessment", and possibly of achievement as well; and values are learned through students' total life experiences, rather than through "direct instruction". So while the school curriculum will supposedly "encourage positive attitudes towards all areas of learning" [italics added], the NZCF absolves itself of any responsibility for ensuring that the active promotion and teaching of values (in whatever form) is appropriate to various individuals, schools, groups, communities or cultures. Yet, perhaps it is this inherent complexity of interest that makes the issue too complicated for our materialistic educational system to address readily. Also, in saying "No schooling is value-free" and that "the content of a school's curriculum reflects what is valued by a society and a school community", the NZCF is (indirectly) acknowledging the existence, relevance and inevitability of a hidden curriculum. The literature tells us that this hidden curriculum may impact adversely on individuals, and groups of students (Adams et al., 2000, pp. 242-247), even though the NZCF asserts that
... the school curriculum, through its practices and procedures, will reinforce the commonly held values of individual and collective responsibility which underpin New Zealand's democratic society.

These values include honesty, reliability, respect for others, respect for the law, tolerance (rangimārie), fairness, caring or compassion (aroha), non-sexism, and non-racism. (MOE, 1993a, p. 21)

While the developers of the NZCF may have social advancement in mind in their intentions for these democratic values, within a market-oriented, competitive educational environment which (directly and indirectly) gives primacy to a focus for learning for economic development and progress, both individual and national (Adams et al. 2000 , p. 123), such "commonly held" values are disputable and thus become somewhat rhetorical.

The English, social studies, Arts, and health and physical education curriculum statements refer directly to attitudes and values:

- The English curriculum (1994) says (in five lines) that critical thinking about literature allows students to "clarify both their own attitudes and values, and those of others" (p. 8).

- The Arts curriculum (2000) lists attitudes, such as those enmeshed in cultural identity and in cultural beliefs, about the contribution art makes to people's lives and the lives of others. These allow individuals and societies to review their past, look at their present, and to envision their future. It lists values, such as integrity, tolerance, and respect, which students are able to develop through learning in the Arts (p. 102).

- Health and physical education (1999) outlines ways in which students can develop responsible attitudes, respect for others, a caring attitude for people and the environment, and a sense of social justice (p. 4).

- Social studies (1997b) integrates processes of values exploration with inquiry and social decision making (p. 16). It is the only statement to elaborate on achievement objectives for values exploration, including analysis of values, through all levels (pp. 52-55).

While the consideration of attitudes and values is relatively integral to English literature and, perhaps even more so, to the Arts, discussions about attitudes and values are explicitly included in topics within the social studies, and health and physical education curricula. Again, 
these two latter learning areas appear to be prime areas for educating for peace, although not exclusively so.

\section{So, What Now? And Where To in the Future?}

As Collinge says, "A curriculum framework is only so many words on paper until it is interpreted by teachers in schools" (1994, p. 45). He also says that while teachers may not call it peace education, there is substantial opportunity and encouragement within the curriculum for teachers to be actively educating for peace. My analysis supports this. Bjerstedt (1992) reminds us that peace education can take varying forms: it can be a specific subject; it can happen outside of classroom learning; it can be handled as a common assignment for all school subjects; or it can focus on values and social interactions and not be attached to any particular subject. His article presents contributions from 40 teachers ${ }^{10}$ world wide that consider inclusion of peace studies in all the learning areas that the New Zealand Curriculum Framework addresses. This re-affirms that educating for peace is possible throughout the curriculum.

However, perhaps what matters most, in the short-and long-term, is teacher awareness of issues of peace, and how their promotion is a way of countering or disrupting negative affects of the hidden curriculum on students, that is, the structural violence of ideological practices within educational institutions. As Byrd (1987) puts it, in "keeping the goal of peace at the forefront of [their] minds" (p. 37), teachers can make a valuable contribution to a more just and peaceful world. He also says, "peace studies must not become cornered into an academic ghetto ... [and that] ... peace is too important for any subject to claim a monopoly of concern or of insight" (p. 37). Again this affirms that it is preferable for all learning areas to incorporate discussions about peace into appropriate topics of study. It also suggests that the absence of peace education, per se, in the NZCF, does not have to be viewed as a defect. As the NZCF stands, there is no risk of relegating peace to one specific area of study in the curriculum, or slot in the timetable, and this can be considered a way of ensuring peace education is a part of all learning.

Having accessed the Department of Education's Peace Studies Draft Guidelines: A Discussion Document (1986) and Peace Studies Update (1987), I initially felt somewhat despondent that these documents had slid into oblivion. Ironically, the end of the Cold War in 1988 defused the political need to address nuclear warfare, which in itself was a motivating factor for peace studies. Yet, if that negotiated peace between America and the (then) USSR contributed to the shelving of the above documents, then perhaps September 11 and the subsequent "war against terrorism" may be reason to revisit that documentation not necessarily to create a new learning area, but more with a view to producing a resource for teachers in all learning areas that would complement the existing curriculum statements. The recent revision by the Ministry of Education (2003) of the former Department of Education (1988) Partners in Peacemaking pamphlet may be a timely (re)beginning for this (re)visiting. Another document worth (re)visiting is NSWDOE's (1988) Educating for Peace in Primary Schools: Curriculum Ideas. As a possible template for drafting a document, and/or a simple diagram for teachers to work from, Figure 1 provides an adaptation of Towards a Peace Perspective K-12 from the NSWDOE document (1988, p. 11). It shows how knowledge objectives link to concepts of peace, how educating for peace aims to empower students through skills development, and demonstrates that educating for peace equips students to analyse, clarify, judge, and acquire certain values.

\section{Concluding thoughts}

Having considered the international literature and analysed the NZCF, I feel far from despondent about peace and education. I believe there is a very positive future for the (re)development of literature and resources relevant to the AoNZ context that will assist teachers in giving more active attention to educating for peace, which, in turn, will contribute to disrupting at least one structure of indirect violence, namely, the hidden curriculum. The New Zealand Foundation for Peace Studies' Cool Schools peer mediation programme, the Peace Foundation's Schools Outreach Programme, annual Schools' Peace Week programmes, Brown and Thomson's (2000) Cooperative Learning in New Zealand Schools, ${ }^{11}$ are representative of the high level of commitment to educating for peace that currently exists in AoNZ. Educating for peace is alive and well. In 2003, the Ministry of Education and The Peace Foundation jointly published an update of the pamphlet, Partners in Peacemaking (1988). The new version, Peace Education in Schools: An Information Pamphlet for Teachers (2003), signals Government's ongoing interest in children developing skills, attitudes and knowledge that promote peaceful classrooms and communities. It includes some good 
Peace Education 243

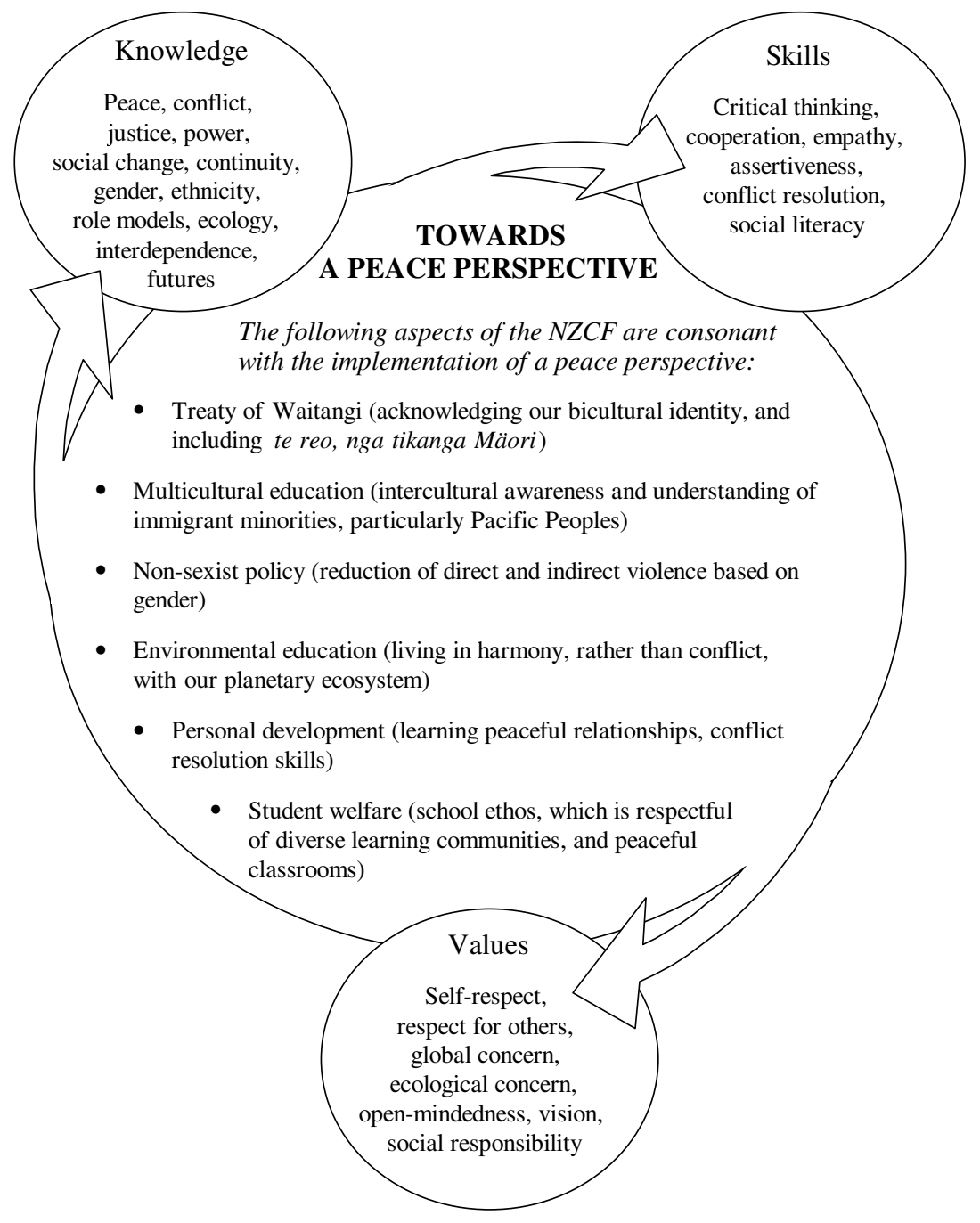

Figure 1 Towards a Peace Perspective

(Adapted from: Educating for Peace in Primary Schools: Curriculum Ideas, 1988. New South Wales Department of Education, p. 11).

\section{Marg Sellers}

basic information, although teachers may say they are already doing what is suggested - in such instances, there is little to inspire them to consider how they might do more about educating for peace within their classrooms.

However, the new pamphlet does potentially pave the way for revisiting the Peace Studies Guidelines. But if the Ministry of Education were to publish an official document it would communicate a serious educational and political commitment to peace - to educationists, teachers, parents, communities, and particularly students as citizens of the future. This would bring a constructively peaceful element to the hidden curriculum. Also, the collaborative process of teachers and existing peace educators in producing such a document, as well as the emergence of the document itself, would be an opportunity to focus knowledge, energy, and resources in such a way that teachers could take ownership of, and be supported in, educating for peace.

It may also instigate research designed to promote a greater understanding of what constitutes a peaceful learning environment, what this means to teachers and students, and what matters to them both in this regard. This would involve listening carefully to teachers' views about their classroom environments, as well as giving voice to students about how they perceive their learning environments. Such research would become a way of raising teachers' and students' awareness of the meaning and applications of peace, (of living peace), and would contribute to the body of knowledge which relates directly to AoNZ.

Virens (1990) predicted that the outbreak of peace that followed the end of the Cold War would be a real threat to the peace movement, as in times of peace we slip easily into complacency. September 11 implicitly becomes an historical reminder that educating for peace should be to the fore within the formal and informal curriculum - both in the official documentation and within schools' practices. It also reminds us that creating non-violent societies with non-violent institutions could become more of a possibility if educating for peace were to become more explicit, more actively practised, and of higher priority. But, regardless of when or whether the political/educational partnership of our school system formally provides for peace education, the New Zealand Curriculum Framework currently provides numerous possibilities for schools, teachers, students, parents and 
communities to jointly participate in seeding, growing and nurturing a peace perspective - a perspective that looks towards educating about peace, educating in peace, and particularly, towards educating for peace.

\section{Notes}

1. Aotearoa New Zealand (AoNZ) honours biculturalism. Aotearoa is the name given by indigenous Māori to the land that Europeans (re)named New Zealand.

2. National Radio Morning Report, 8.45 a.m.,12 September 2001. This was not to suggest that indirect violence is exclusive to Westernism, rather that it is culturally, ethically, and morally more appropriate for "Westerners" (Americans and their allies) to primarily address violence within Westernism, and within our own societies.

3. As alluded to by Marshall McLuhan (1964).

4. I use "confront" throughout this article in terms of "facing up to and dealing with (a problem)" (Concise Oxford Dictionary, 1999). This meaning implies the acceptance of a non-violent approach to addressing problematic situations.

5. Interestingly, the implication that attitudes of "weakness" are inferior goes unchallenged. This implied "inferiority" is addressed by the work of microbiologists, Lynn Marquis and Dorian Sagan. They say, "Competition in which the strong wins has been given a good deal more press than cooperation. But certainly weak organisms have survived in the long run by being part of collectives, while the so-called strong ones, never learning the trick of cooperation, have been dumped onto the scrap heap of evolutionary extinction" (1986, cited in Briggs \& Peat, 1989).

6. The term "social sciences" is referred to as "social studies" in subsequent documents.

7. Subsequently referred to as "health and physical education".

8. Namely, conflict, peace, justice, power, social change and continuity (preserving what is valuable, modifying what is undesirable), gender, ethnicity, role models (of peacemaking), ecology, interdependence (economic, environmental, and communications), and futures (both probable and preferable alternatives) (NSWDOE, 1988, pp. 7-8).

9. The visual representation (MOE, 1993a, p. 5) of how the principles, essential learning areas, essential skills, and attitudes and values are linked places attitudes and values at the point of the arrow. This implies they ease, enable and are essential to the skills processes and learning area implementation, and are pivotal to the enacting of the principles. 10. Including Jim Collinge from AoNZ.
11. It was beyond the scope of this essay to address "cooperative learning" per se, which is well documented in the literature. Suffice it to say that in the same way that "peace education" risks being relegated to a specific part of the curriculum, "cooperative learning" is also at risk of being compartmentalised. I have suggested that the notion of "educating for peace" makes for more ready integration of peace education into the curriculum. Similarly, approaching "cooperative learning" from a perspective of "learning cooperatively" may be a way of encouraging teachers to put this into practice more actively.

\section{References}

Adams, P., Clark, J., Codd, J., O’Neill, A-M., Openshaw, R., \& Waitere-Ang, H. (2000). Education and society in Aotearoa New Zealand: An introduction to the social and policy contexts of schooling and education. Palmerston North: Dunmore Press.

Aspin, D. N. (1984). "Peace studies" in the curriculum of educational institutions: An argument against indoctrination. In J. J. Wellington (Ed.), Controversial issues in the curriculum. Oxford: Basil Blackwell.

Bjerstedt, A. (1992, May). Peace education and traditional school subjects. Peace Education Miniprints, 80, 1-37.

Briggs, J., \& Peat, F. D. (1989). Turbulent mirror: An illustrated guide to chaos theory and the science of wholeness. New York: Harper \& Row.

Brown, D., \& Thomson, C. (2000). Cooperative learning in New Zealand schools. Palmerston North: Dunmore Press.

Buckland, J., Jones, A., \& Duncan, Y. (Eds.), (1990). Peace education: The Aotearoa/New Zealand way. Auckland: Students and Teachers for Peace.

Byrd, P. (1987). Peace studies: a case for careful development. Cambridge Journal of Education, 17(1), 35-40.

Catholic Education Office, Melbourne \& the New South Wales Department of Education. (1987). Educating for peace: Explorations and proposals: Report to the Curriculum Development Council. Canberra: Curriculum Development Council.

Collinge, J. (1994). Peace education across the curriculum: Some perspectives from New Zealand. Peace, Environment and Education, $5(1), 37-52$.

Cox, C., \& Scruton, R. (1984). Peace studies: A critical survey. [Place unknown]: Alliance Publishing.

Department of Education. (1986). Peace studies draft guidelines: A discussion document. Wellington: Department of Education. 
Department of Education. (1987). Peace studies update March 1987. Wellington: Department of Education.

Department of Education. (1988). Partners in peacemaking. Wellington: Department of Education.

Freire, P. (1974). Pedagogy of the oppressed. New York: Continuum.

Hicks, D. (1987). Education for peace: Principles into practice. Cambridge Journal of Education, 17(1), 2-12.

Hicks, D. (1988). Peace and conflict. In B. Carrington \& B. Troyna (Eds.), Children and controversial issues (pp. 172-188). London: Falmer Press.

Howson, G. (1994). Mathematics in the New Zealand curriculum. Auckland: Education Forum.

McLuhan, M. (1964). Understanding media: The extensions of man. London: Routledge \& Kegan Paul.

Ministry of Education (MOE). (1993a). The New Zealand Curriculum Framework: Teanga marautanga o Aotearoa. Wellington: LearningMedia.

Ministry of Education. (1993b). Science in the New Zealand curriculum. Wellington: Learning Media.

Ministry of Education. (1994). English in the New Zealand curriculum. Wellington: Learning Media.

Ministry of Education. (1995). Technology in the New Zealand curriculum. Wellington: Learning Media.

Ministry of Education. (1996). Te whāriki: He whāriki mātauranga mōngāa mokopuna o Aotearoa: Early childhood curriculum. Wellington: Learning Media.

Ministry of Education. (1997a). Developing mathematics programmes. Wellington: Learning Media.

Ministry of Education. (1997b). Social studies in the New Zealand curriculum. Wellington: Learning Media.

Ministry of Education. (1999). Health and physical education in the New Zealand curriculum. Wellington: Learning Media.

Ministry of Education. (2000). The Arts in the New Zealand curriculum. Wellington: Learning Media.

Ministry of Education \& The Peace Foundation. (2003). Peace education in schools: An information pamphlet for teachers. Auckland: The Peace Foundation

Mische, P. M. (1992). Toward a pedagogy of ecological responsibility: Learning to reinhabit the earth. Peace, Environment and Education, 3(3), 37-56
New South Wales Department of Education. (1988). Educating for peace in primary schools: Curriculum ideas. Sydney: NSWDOE.

New Zealand Foundation for Peace Studies. (1992). The cool schools peer mediation programme. Auckland: Author.

Pearsal, J. (Ed.). (1999). Concise Oxford Dictionary (10th ed.) Oxford: Oxford University Press.

Reardon, B. A. (1997). Human rights as education for peace. In G. J. Andreopoulos \& R. P. Claude (Eds.), Human rights for the twenty-first century (pp. 21-34) . Philadelphia: University of Pennsylvania Press.

Sharp, R. (1984). Varieties of peace education. In R. Sharp (Ed.), Apocalypse No: An Australian guide to the arms race and the peace movement (pp. 248-266). Sydney: Pluto Press.

Stephenson, C. M. (1989). The evolution of peace studies/peace research: An historical and international perspective. In $D$. Bretherton et al. (Eds.), Peace studies in Australia and New Zealand: A guide to tertiary and community courses (pp. 18-28). Melbourne: Victoria Association for Peace Studies.

The Peace Foundation. (n.d.). Schools' peace week 2002 pamphlet. Auckland: The Peace Foundation.

The Peace Foundation. (n.d.). UN decade for peace and non-violence: Schools outreach programme pamphlet. Auckland: The Peace Foundation.

Vriens, L. (1990). Peace education in the nineties: a reappraisal of values and options. Peace, Environment and Education, 1(1), 5-20.

Wahlström, R. (1992). Promoting commitment to peace and environmental responsibility. Peace, Environment and Education, 3(1), 33-43

Wessells, M. G. (1993). Building a sustainable world: Technology, values, and social choices. Peace, Environment and Education, 4(1), 3-27.

Wulf, C. (1992). Education for Peace. Peace, Environment and Education, 3(2), 3-10.

\section{The author}

Marg Sellers recently completed a BA (Hons) in education at Victoria University. Her study interests include philosophical approaches to education within a multiplicity of post-structural perspectives. In practical terms, seeking possibilities for "peace educating" within curriculum grew through these philosophical interests. 